УДК 81'243:37.011.3-051:347.115

DOI: $\underline{10.35619 / \text { iiu.v2i13.354 }}$

Tamara Bilous

$\mathrm{PhD}$ in Pedagogy, Associate Professor, Associate Professor

Rivne State University for the Humanities,

Rivne, Ukraine

ORCID: 0000-0001-7411-4623

e-mail:tamara.bilous@ukr.net

Iryna Vietrova

$\mathrm{PhD}$ in Pedagogy, Associate Professor, Associate Professor

Rivne State University for the Humanities,

Rivne, Ukraine

ORCID: 0000-0003-3673-7082

e-mail:irvetr@ukr.net

Olena Verovkina

$\mathrm{PhD}$ in Psychology, Associate Professor, Associate Professor

Rivne State University for the Humanities,

Rivne, Ukraine

ORCID: 0000-0002-1333-6668

e-mail:yelena5678@ukr.net

\title{
THE BALANCE BETWEEN LANGUAGE ACQUISION AND LANGUAGE LEARNING IN ELC
}

\begin{abstract}
The article is devoted to the to the actual problem of the balanced use of English language teaching methods, some of which are considered by foreign researchers as close to the natural development of the child's language, and others are viewed as purely educational. Based on the analysis of foreign researches, the authors of the study clarified the concepts of "second language acquisition" and "second language learning", outlined their fundamental difference and importance in the process of studying English. It has been observed that some scholars prefer only methods of second language acquisition that resemble the natural process of a child's native language development. There is another vision of successful foreign language learning, whose proponents believe that when teaching a foreign language one should use both exercises that give an idea of the language, and activities that resemble the natural process of language acquisition, where the first can't be ignored and plays an important role. The article suggests the examples of different approaches to the use of educational material at English language classroom. It is noted that their choice depends on the teacher, his understanding of the real language functioning in the community. $\mathrm{T}$ has been suggested, that wide exposure to a second language can be provided by extensive reading and listening, in particular out of ELC. This can be assisted by parents and their involvement to students' studying. The results of a survey of students on their

(C) Tamara Bilous, Iryna Vietrova,

Olena Verovkina,2021


preferences in mastering the English language and observation of the real situation in the classroom are presented. The paper discusses the debatable nature of the problem and need for its further development is emphasized.

Keywords: second language acquisition, second language learning, first language, second language.

Problem statement. The integration of the national education system into the European and world educational space forms a public demand for the renewal of the teachers' professional education system. The modern Ukrainian school needs a new kind of a foreign language teacher, whose task is not just to teach according to traditional schemes, but to make difference in an independent and responsible choice of forms, means and content of education. New requirements for the educational activity of the teacher create objective preconditions for the formation of his professional competences and readiness to further develop students' educational awareness.

Understanding the trends of the new educational paradigm today is complicated by the insufficient formation of general meanings, which are embedded in the basic concepts and terms. One can notice the ambiguity of interpretations among the representatives of professional and pedagogical field in domestic and foreign scientific literature. The discussion on the issue of the difference and balance between second language acquisition (SLA) and second language learning (SLL) in the English Language Classroom (ELC) exacerbates the relevance of the chosen topic.

The topicality of the theme can be explained by minimum knowledge in distinguishing the very essence of each aspect, in particular, when it goes about the implementation of SLA and SLL related activities into practice of the English language teacher.

Research publications analysis. Any language is the means we use to convey ideas from one person to another, and acquiring languages remains one of the most fascinating aspects of human development. From the first monosyllabic utterances to the use of complex, nuanced and context-specific structures, both the rate of progress and the stages of language acquisition have been the focus of innumerable research studies in the fields of developmental psychology, linguistics and pedagogy.

Before identifying the differences attributed to SLA and mere classroom learning, it is necessary to establish the meaning of two key terms that will be used throughout this paper: acquisition and learning.

Second language (L2) acquisition theory is built on models of first language (L1) acquisition and on learning theory. As each aspect evolves independently from one another, it is important to return to the source and integrate insights from relevant developments.

It should be noted, that Language acquisition theory is based on the neuropsychological processes (Maslo, 2007). It is opposed to learning and it is considered to be a subconscious process similar to that, by which children 
acquire their first language (Kramina, 2000). Thus, language acquisition is an integral part of the unity of all languages (Robbins, 2007).

Language learning is viewed as a conscious process, the product of either formal learning situation or a self-study. (Kramina, 2000). So, language learning is an integral part of the unity of all languages as well (Robbins, 2007). So, there arises a question: what is the difference between them?

An American linguist S. Krashen, a developer of SLA hypothesis, claims, that there is a strict distinction between acquisition and learning. S. Krashen sees acquisition as a purely subconscious process and learning as a conscious process, and claims that improvement in language ability depends only on acquisition and never on learning. He deliberately has marked the boundary between these two aspects of studying a second language. In more simplified way, it can be presented as following:

\begin{tabular}{|l|l|}
\hline \multicolumn{1}{|c|}{$\begin{array}{c}\text { SECOND LANGUAGE } \\
\text { ACQUISITION }\end{array}$} & \multicolumn{1}{c|}{$\begin{array}{c}\text { SECOND LANGUAGE } \\
\text { LEARNING }\end{array}$} \\
\hline subconscious process & conscious process \\
\hline meaningful interaction & formal instruction \\
\hline communicative act & Grammar \\
\hline
\end{tabular}

Figure 1. Acquisition/learning distinction

S. Krashen insists, that in the English language classroom (ELC), where English is taught as a second language, the biggest priority should be given to acquisition, not learning, since acquisition totally reflects the process of acquiring the first (native) language and is the only way to successfully master a foreign language.

Nonetheless, the scientist received a lot of criticism from other methodologists. For instance, Zafar states, that acquisition could be better understood when described as a process enriched by the learning activities. Instead of drawing a borderline, separating acquisition and learning into two discrete disciplines, the cross-currents at both are constantly at work in studying and are to be acknowledged and explained. (Zafar, 2009).

Gass and Selinker argued, that the difficulty to perceive how acquisition and learning "housed" in two separate linguistic systems, could be put into use by L2 learners. (Gass \& Selinker, 1994).

One should admit, that S. Krashen did not seem to be anxious by the criticism. (Zafar, 2009). For S. Krashen, acquisition, picking up a language naturally like children do in their L1, is a process still available to adults, and is far more important than language learning. Knowledge gained through one means (e.g., learning) cannot be internalised as knowledge of the other kind (e.g., acquisition), and only the acquisition system produces language, whereas learning serves only as a monitor of the acquired system, checking the correctness of utterances according to the formal knowledge stored in.

To our way of thinking, S. Krashen's viewpoint is a good and solid foundation for the accepted and widely used communicative approach in 


\section{Інноватика у вихованні. Випуск 13.Том 2. 2021.}

teaching a foreign language. The analysis of modern researches shows that, despite significant theoretical achievements in solving the problem under analysis, there still remain some issues, which are worth detailed reflection. So, in this research the attempt to find the balance between two ways of mastering a second language will be made.

The aim of the paper is to analyze the possible activities in the English language classroom, which can be referred to second language acquisition or second language learning and their impact on the students in terms of their effectiveness in studying a second language (English).

Presentation of the main research material. Lightbown and Spada (2001), have admitted, that language acquisition occurs during the early years of one's life - usually in early childhood before age three - and that it can be estimated as a part of people's growing up. In contrast, learning is defined as a more conscious and explicitly sequenced process of "accumulating knowledge of linguistic features such as vocabulary, sentence structure and grammar, typically in an institutional setting" (Yule, 1985). The difference between these ways of developing language competence is manifested most clearly in the outcomes: the contextual understanding of the language is gained through acquisition, and knowledge about the language: "knowing the rules, being aware of them, and being able to talk about them" is provided through learning, (Krashen, 1982; Schmidt, 1983).

In terms of studying a second language, English language classroom is a setting, where the target language is taught only as a subject, and is not commonly used as medium of communication outside the classroom. In other words, it is the place where the learners have no contact with the target language outside the language classroom.

One can presume, that two contextual aspects are of potential importance in language classroom settings. One concerns the learning situation to be found in the classroom. The other is the level of support which is given to the foreign second language program. With regard to the classroom learning situation, we should point out, that the role of relationships between teacher and student are likely to be crucial.

In the case of traditional approaches to language teaching, where the target language is perceived primarily as an object to be mastered by learning about its formal properties, the teacher typically acts as an "informer" and the learner as an "information seeker".

However, considering innovative approaches, where the emphasis is put on the use of the target language in "social behavior", a number of different role relationships are possible, depending on whether the participants are "playing at talk", as in role play activities, or have a real-life purpose for communicating, as in information gap activities. In this case, the teacher can be a "producer" or a "referee" and the learner performs as an "actor" or a "player". The nature of these classroom roles is likely to influence the level and type of proficiency the students develop. 
There are multiple pedagogical theories and approaches that can guide the decisions a teacher makes in the classroom. Some of them can be non-effective. (Langer,1997) presents the following myths of learning:

1) the basics need to be learned so well that they become second nature;

2) paying attention means staying focused on one thing at a time;

3) delaying gratification is important;

4) rote memorization is necessary for education;

5) there are right and wrong answers.

In the classroom, teachers offer repetitive exercises that ask students to perform a task the same way regardless of the context or students. Teachers often present the task as if it can only be performed one way. Langer argues that when individuals are told that there is only one right way to perform a task, it limits their ability to make the material their own and use the information in creative ways. In reality, no individual performs a task in the same way.

At this stage of our research it will be logical to ponder on the possible ways, by which students study grammar. Definitely, grammar studying can be viewed only as a learning activity and has nothing to do with acquisition. Lee and Van Patten identify three types of drills: mechanical, meaningful, and communicative (Lee \& Van Patten, 2003). Mechanical drills, such as transformation and substitution drills, do not promote acquisition, because learners do not have to attend to meaning in order to produce utterances. Learners performing mechanical drills do not need even to understand their own utterances. They work to learn the basics through rote memorization without personal relevance.

In meaningful drills, meaning is in focus but the answer is known before the question is asked. Students engaged in meaningful drills display knowledge of form but do not necessarily use language creatively. Consequently, they search for the one right answer. In communicative drills, the answer depends on the student and is not already known.

As a matter of fact, one and the same material can be given as a learning activity or, on the contrary, as an acquisition one. The example is shown on the following table.

Table 1

\begin{tabular}{|l|l|l|l|}
\hline Activity & Learning & Acquisition & Both \\
\hline Listening to an English song & & & V \\
\hline Reading a poem & & & V \\
\hline Writing a blog & & & V \\
\hline Reading/Writing an e-mail & & & V \\
\hline Communicating with a native speaker & & V & \\
\hline Doing some grammar exercises & V & & \\
\hline Review your peer's essay & & & V \\
\hline $\begin{array}{l}\text { Interacting with your peers in a group } \\
\text { activity }\end{array}$ & & V & \\
\hline Playing a language game & & & V \\
\hline Watching an English film & & & V \\
\hline
\end{tabular}




\begin{tabular}{|l|l|l|l|}
\hline Learning English words from a list & V & & \\
\hline $\begin{array}{l}\text { Taking part in a role play in pairs in } \\
\text { class }\end{array}$ & & V & \\
\hline
\end{tabular}

When examining and deciding how to apply each activity in terms of acquisition/learning theory, one may notice, that almost each activity can be implemented in both ways with only some exceptions. Ticks in the relevant boxes demonstrate, which of them can be used accordingly.

For instance, listening to an English song can be given with the instruction to write out the verbs in Past Simple. In this way this activity can be referred to Language learning. In case the song is used as a short relaxation break in the middle of the lesson, it can be estimated as Language acquisition, which influences students on their subconscious level. Similarly, reading a poem can be done just for pleasure, and on the other hand it can be a conscious process, which aims to memorise it.

On top of that, it should be stressed out, that wide exposure to a second language can be provided by extensive reading and listening, in particular out of ELC. This can be assisted by parents and their involvement to students' studying.

Thus, one can presume, that the balance between language acquisition and language learning largely depends upon the decision, made by a teacher, whether he/she prones to focus on learning, or his/her goal is to involve students into interaction. Again, it should be pointed out, that much depends on the outcomes of every lesson or extra-curricular activities.

Our observations at secondary schools have shown that in the English language classroom only about $50 \%$ of studying time is given to language acquisition activities. Being interviewed, the students mostly reported that they prefer acquisition activities to learning, though $45 \%$ of them admitted that learning rules and drilling are important as well for having better command of the language.

Conclusions and perspectives of further research. All things considered, the team of the authors of this paper would like to stand their ground, as to the fact, that they support most of S. Krashen's ideas. Language acquisition techniques should predominate in every English Classroom. Secondly, a teacher is the one, who absolutely must provide the students'access to language acqusition, no matter, what school he/she is working at. On top of that, a teacher remains the only one, who decides upon priority tasks, which should be given to the students. In spite of the general viewpoint, we still remain on the position that only a teacher can donate to language acquisition, otherwise he/ she will never have a possibility to provide his students' language fluency..

The aspects of this research still wait for many discussions. Thus, in the long run, the themes of acquisition and learning will find their ways in later research works. 


\section{REFERENCES}

Maslo, E. (2007). Transformative Learning Space for Life-Long Foreign Languages Learning. International Nordic-Baltic Region Conference of FIPLV Innovations in Language Teaching and Learning in the Multicultural Context 15-16 ${ }^{\text {th }}$ June, 2007, Riga, Latvia.

Kramiña, I. (2000). Lingo - Didactic Theories Underlying Multi - Purpose Language Acquisition. University of Latvia

Robbins, D. (2007). Vygotsky's and Leontiev's Non-classical Psychology Related to Second Language Acquisition. International Nordic-Baltic Region Conference of FIPLV Innovations in Language Teaching and Learning in the Multicultural Context 15-16 ${ }^{\text {th }}$ June, 2007, Riga, Latvia.

Langer, E. (1997). The power of mindful learning. Reading, MA: Peruses.

URL: http://www.iranelt.com/index.php/introduction-to-sla

URL: https://www.researchgate.net/publication/233566784_Input_filters_i n_second_language_acquisition

URL:https://www.academia.edu/11570891/03_The_Study_of_Language_ George_Yule

URL: https://pubmed.ncbi.nlm.nih.gov/33244724/

\section{ДО ПИТАННЯ ЩОДО БАЛАНСУ МІЖ ОВОЛОДІННЯМ МОВОЮ ТА ВИВЧЕННЯМ МОВИ НА УРОКАХ АНГЛІЙСЬКОЇ}

Білоус Тамара

кандидат педагогічних наук, доцент, доцент кафедри практики англійської мови Рівненського державного гуманітарного університету, м. Рівне, Україна ORCID: 0000-0001-7411-4623, e-mail:tamara.bilous@ukr.net

Ветрова Ірина

кандидат педагогічних наук, доцент, доцент кафедри практики англійської мови Рівненського державного гуманітарного університету, м. Рівне, Україна ORCID: 0000-0003-3673-7082, e-mail:irvetr@ukr.net

Верьовкіна Олена кандидат психологічних наук, доцент, доцент кафедри практики англійської мови Рівненського державного гуманітарного університету,

м. Рівне. Україна ORCID:0000-0002-1333-6668, e-mail:yelena5678@ukr.net 


\section{Інноватика у вихованні. Випуск 13.Том 2. 2021.}

Анотація. Стаття присвячена актуальній проблемі збалансованого використання методів навчання англійської мови, одні 3 яких розглядаються зарубіжними дослідниками як такі, що наближені до природнього розвитку мови дитини, а інші вважаються суто навчальними. На основі аналізу зарубіжних праць автори дослідження уточнили поняття «оволодіння другою мовою» та «вивчення другої мови», окреслили їх принципову різницю та значення у процесі навчання англійської мови. Простежено, що деякі зарубіжні науковці надають перевагу лише методам оволодіння другою мовою, які нагадують природній процес набуття дитиною рідної мови. Існує інше бачення успішного вивчення іноземної мови, прихильники якого вважають, що під час навчання іноземної мови слід використовувати як вправи, що надають уявлення про мову, так $\mathrm{i}$ види діяльності, які нагадують природній процес набуття мови, при чому перші не можуть бути проігноровані та відіграють важливу роль у процесі навчання. Узагальнено, що за умови використання інноваційних підходів до вивчення іноземної мови один і той самий навчальний матеріал може використовуватися у спосіб, що нагадує природній розвиток мови дитини, або у класичний спосіб вивчення певного шару інформації. У статті наведені приклади різних підходів до використання навчального матеріалу на уроках англійської мови. Зазначено, що їх вибір залежить від учителя, його розуміння важливості реального функціонування мови у ситуаціях повсякденного спілкування. Зазначено, що широкий доступ до другої мови може бути забезпечений екстенсивним читанням та слуханням, зокрема поза роботою на уроках англійської мови. Цьому можуть сприяти батьки та їх залучення до навчання учнів. Наведено результати опитування учнів щодо їх преференцій в оволодінні англійською мовою та спостереження за реальною ситуацією на уроках. У роботі зазначений дискусійний характер проблеми та необхідність її подальшої розробки.

Ключові слова: оволодіння другою мовою, вивчення другої мови, перша мова, друга мова.

Стаття надійшла до редакиії 30. 04. 2021p. 